\title{
DAMPAK YURIDIS PEMERIKSAAN SETEMPAT (GERECHTELIJKE PLAATSOPNEMING) DALAM HUKUM ACARA PIDANA DIPANDANG DARI ASPEK PERTIMBANGAN HUKUM PUTUSAN PERKARA PIDANA
}

\author{
Ratih Mannul Izzati ${ }^{1}$, Nyoman Serikat Putra Jaya ${ }^{2}$
}

\begin{abstract}
ABSTRAK
Pembahasan dan pengkajian secara teoritis normatif mengenai Dampak Yuridis Pemeriksaan Setempat (gerechtelijk plaatsopneming) Dalam Hukum Acara Pidana Dipandang Dari Aspek Pertimbangan Hukum Putusan Perkara Pidana, dimaksudkan untuk mencari solusi hukum dari dampak kekosongan hukum (recht vacuum) yang timbul mengenai penerapan pemeriksaan setempat. Hal ini dikarenakan tidak ada ketentuan yang mengatur secara normatif di dalam Kitab Undang-Undang Hukum Acara Pidana (KUHAP) mengenai aplikasi pemeriksaan setempat.

Permasalahan yang ditampilkan dalam tesis ini, diantaranya: Bagaimana kebijakan aplikasi pemeriksaan setempat (gerechtelijke plaatsopneming) dalam hukum acara pidana pada saat ini, Apa fungsi pemeriksaan setempat (gerechtelijke plaatsopneming) dalam pertimbangan hukum putusan perkara pidana, Bagaimana dampak yuridis pemeriksaan setempat (gerechtelijke plaatsopneming) dalam hukum acara pidana, serta Bagaimana formulasi pemeriksaan setempat (gerechtelijke plaatsopneming) dalam pembaharuan Kitab Hukum Acara Pidana yang akan datang.

Kajian ini menggunakan metode pendekatan hukum normatif dengan spesifikasi penelitian deskriptif analitis, menggunakan jenis data yang terarah pada penelitian data sekunder yang dikumpulkan melalui studi kepustakaan dan studi dokumenter dengan menggunakan metode sistimatis yang dianalisis secara kualitatif normatif.

Berdasarkan hasil kajian dapat diketahui bahwa yang menjadi kebijakan aplikasi pemeriksaan setempat dalam hukum acara pidana pada saat ini merupakan kebijakan yang berasal dari penemuan hukum oleh hakim dengan metode konstruksi hukum, yang mengedepankan keadilan substansial dan asas peradilan cepat. Selanjutnya, fungsi pemeriksaan setempat dalam pertimbangan hukum putusan perkara pidana digunakan untuk keyakinan hakim, pertimbangan untuk menetapkan penyerahan barang bukti serta menambah keterangan bagi hakim. Kemudian dampak yuridis pemeriksaan setempat (gerechtelijke plaatsopneming) dalam hukum acara pidana adalah, tidak adanya unifikasi (keseragaman) aturan mengenai pemeriksaan setempat dalam praktik hukum acara pidana pada saat ini, yang meliputi: ketidakseragaman mengenai para pihak yang mengikuti pemeriksaan setempat dalam perkara pidana dan ketidakseragaman mengenai uraian pemeriksaan setempat dalam pertimbangan hukum pada putusan perkara pidana yang tidak jelas dan lengkap. Oleh karena masih terjadi ketidakseragaman terkait pemeriksaan setempat dalam hukum acara pidana pada saat ini, maka perlu formulasi dalam pembaharuan Kitab Undang-Undang Hukum Acara Pidana (KUHAP) secara jelas tentang aturan ruang lingkup serta tata cara pemeriksaan setempat dalam hukum acara pidana untuk menciptakan kepastian hukum.
\end{abstract}

Kata Kunci: Pemeriksaan Setempat, Hukum Acara Pidana, Pertimbangan Hukum Putusan Perkara Pidana.

\footnotetext{
${ }^{1}$ Mahasiswa Program Studi Magister Ilmu Hukum Undip

${ }^{2}$ Dosen Program Studi Magister Ilmu Hukum Undip
} 


\section{PENDAHULUAN}

\section{A.1. LATAR BELAKANG}

Penegakan Hukum Pidana di Indonesia tidak dapat dilaksanakan apabila hanya berdasarkan hukum pidana materiil semata. Penegakan hukum pidana dapat dilaksanakan, apabila terdapat peraturan-peraturan mengenai cara memelihara dan mempertahankan hukum pidana materiil yang disebut dengan hukum pidana formil. Peraturan perundang-undangan di Indonesia yang mengatur mengenai hukum pidana formil ialah Kitab Undang-Undang Hukum Acara Pidana (KUHAP).

Pemberlakuan KUHAP di Indonesia diharapkan membawa perubahan positif dalam penegakan hukum pidana di Indonesia. Namun dalam perkembangannya terdapat beberapa kelemahan maupun kekurangan yang terdapat pada aturan-aturan di dalam KUHAP. Kekurangan dan kelemahan dalam KUHAP tersebut, antara lain : terdapat pasal-pasal yang tidak sesuai dengan praktik penegakan hukum, dan terdapat kekosongan hukum (recht vacuum) pada ketentuan KUHAP yang dapat berpengaruh pada upaya penegakan hukum pidana di Indonesia.

Berdasarkan kekurangan dan kelemahan KUHAP tersebut, timbul konsekuensi logis untuk diadakannya pembaharuan dalam KUHAP. Pembaharuan dalam KUHAP tersebut merupakan salah satu dari tahap penegakan hukum pidana di Indonesia.

Pembaharuan dalam KUHAP ini, sangat diperlukan dalam praktik penegakan hukum. Salah satunya, pembaharuan KUHAP mengenai penegakan hukum dalam tahapan penerapan /aplikatif yang menjadi wewenang lembaga yudikatif. Lembaga yudikatif (Pengadilan) ini juga merupakan salah satu sub sistem peradilan pidana. Melalui lembaga pengadilan ini dapat diharapkan terciptanya penegakan hukum pidana yang konsekuen di Indonesia.

Produk dari Pengadilan yang dirasakan dapat memberikan rasa keadilan, kepastian hukum dan kemanfaatan dalam masyarakat ialah putusan hakim. Putusan Hakim tersebut tercipta dari proses-proses persidangan yang sesuai dengan hukum acara pidana yang berlaku (KUHAP).

Namun, pada praktiknya beberapa ketentuan KUHAP masih berlaku umum dan bersifat abstrak, sehingga tidak dapat diterapkan begitu saja secara langsung di persidangan. Oleh karena itu, maka hakim sebagai pemegang peran penting dalam proses persidangan perlu melakukan penemuan hukum (rechtsvinding).

Menurut Sudikno Mertokusumo, pada intinya penemuan hukum merupakan proses konkretisasi dan individualisasi peraturan hukum (das sollen) yang bersifat umum 
dengan mengingat akan peristiwa konkret (das sein) tertentu. ${ }^{3}$

Contoh konkrit proses persidangan yang memerlukan penemuan hukum oleh hakim dalam ranah hukum acara pidana, terjadi pada persidangan perkara pidana di pengadilan Negeri di Indonesia. Perkara-perkara tersebut, antara lain :

1. Perkara pidana nomor : 198/Pid.B/2009/PN.Ung jo nomor : 37/Pid/2010/PT.Smg jo nomor : 1074K/PID/2010 mengenai tindak pidana kesusilaan (Pasal 284 KUHP yaitu zina).

2. Perkara pidana nomor : 235/Pid.B/2010/PN.Ung mengenai tindak pidana perlindungan konsumen (Pasal 8 Ayat (1) huruf b, c jo Pasal 62 Ayat (1) UndangUndang Nomor 8 Tahun 1999 tentang Perlindungan Konsumen jo Pasal 55 Ayat (1) ke-1 KUHP, yaitu secara bersama-sama memproduksi dan atau memperdagangkan barang dan atau jasa yang tidak sesuai dengan berat bersih, isi bersih atau netto dan jumlah dalam hitungan, sebagaimana dinyatakan dalam label atau etiket barang dalam hitungan menurut ukuran yang sebenarnya) .

3. Perkara pidana nomor : 95/Pid.Sus/2010/PN.Ska mengenai tindak pidana menghuni rumah tanpa persetujuan dan izin dari pemiliknya (Pasal 12 Ayat (1) jo Pasal 36 Ayat

(4) Undang-undang Nomor 4 Tahun 1992 tentang Perumahan dan Pemukiman)

Pada proses pembuktian perkara-perkara pidana tersebut di persidangan, hakim melakukan pemeriksaan terhadap 5 alat bukti yang diatur dalam Pasal 184 KUHAP. Selain itu, hakim pada perkara tersebut juga melakukan pemeriksaan setempat.

Pelaksanaan pemeriksaan setempat dalam proses persidangan perkara-perkara pidana tersebut merupakan peran hakim untuk bersikap aktif dalam mencari kebenaran materiil dengan melakukan penemuan hukum. Hal ini dikarenakan di dalam KUHAP (Hukum Acara Pidana) tidak ada ketentuan yang mengatur secara normatif mengenai pemeriksaan setempat beserta ruang lingkup dan tata caranya. Padahal pemeriksaan setempat (gerechtelijke plaatsopneming) diperlukan dalam proses persidangan pidana untuk mendukung pembuktian perkara pidana di persidangan (das sein).

Selama ini, Pemeriksaan setempat (gerechtelijke plaatsopneming) hanya diatur secara normatif dalam ranah hukum acara perdata saja. Pemeriksaan Setempat (gerechtelijke plaatsopneming) dalam hukum acara perdata diatur dalam Pasal 153 HIR (Herzeine Inlandsch Reglement ).

Berdasarkan pemaparan di atas ketimpangan yang terjadi antara das sein dan das sollen dalam proses persidangan perkara pidana dengan ketentuan dalam KUHAP,

3 Sudikno Mertokuusumo, Penemuan Hukum Sebuah Pengantar, Penerbit : Liberty, Yogyakarta, 2001, hlm : 37 
membuat hakim bersikap aktif dengan melakukan terobosan hukum acara pidana. Hal ini bertujuan untuk memberlakukan pemeriksaan setempat sebagai bagian dari proses persidangan pidana. Dengan demikian demi terciptanya kepastian hukum, maka diperlukan pembaharuan hukum acara pidana untuk mengatur mengenai ruang lingkup serta tata cara pemeriksaan setempat dalam proses persidangan pidana.

Namun, pemberlakuan pemeriksaan setempat (gerechtelijke plaatsopneming) dalam hukum acara pidana, ternyata menimbulkan permasalahan mengenai dampak yuridis pemeriksaan setempat dalam hukum acara pidana. Sehingga untuk mencari solusi hukum dari pemasalahan tersebut, maka penulis merasa perlu untuk mengadakan penelitian dengan judul: "Dampak Yuridis Pemeriksaan Setempat (gerechtelijke plaatsopneming) Dalam Hukum Acara Pidana Dipandang Dari Aspek Pertimbangan Hukum Putusan Perkara Pidana “.

\section{A.2. PERMASALAHAN}

Berdasarkan latar belakang tersebut, dirumuskan beberapa permasalahan yang akan dibahas dalam penelitian ini adalah sebagai berikut:

1. Bagaimana kebijakan aplikasi pemeriksaan setempat (gerechtelijke plaatsopneming) dalam hukum acara pidana pada saat ini ?

2. Apa fungsi pemeriksaan setempat (gerechtelijke plaatsopneming) dalam pertimbangan hukum putusan perkara pidana?

3. Bagaimana dampak yuridis pemeriksaan setempat (gerechtelijke plaatsopneming) dalam hukum acara pidana?

4. Bagaimana formulasi pemeriksaan setempat (gerechtelijke plaatsopneming) dalam pembaharuan Kitab Hukum Acara Pidana yang akan datang?

\section{A.3. TUJUAN PENELITIAN}

Adapun tujuan yang hendak dicapai dalam penelitian ini adalah sebagai berikut:

1. Untuk mengetahui dan menganalisis kebijakan aplikasi pemeriksaan setempat (gerechtelijke plaatsopneming) dalam hukum acara pidana pada saat ini.

2. Untuk mengetahui dan menganalisis fungsi pemeriksaan setempat (gerechtelijke plaatsopneming) dalam pertimbangan hukum putusan perkara pidana.

3. Untuk mengetahui dan menganalisis dampak yuridis pemeriksaan setempat (gerechtelijke plaatsopneming) dalam hukum acara pidana.

4. Untuk mengetahui dan menganalisis formulasi pemeriksaan setempat dalam pembaharuan Kitab Hukum Acara Pidana yang akan datang. 


\section{A.4. TINJAUAN PUSTAKA}

1. Tinjauan Umum mengenai Pemeriksaan Setempat (gerechtelijke plaatsopneming).

Pemeriksaan setempat (gerechtelijke plaatsopneming) merupakan tindakan hukum yang erat kaitannya dengan pembuktian. Hal ini dikarenakan, pemeriksaan setempat digunakan untuk menguatkan atau memperjelas fakta atau peristiwa maupun objek barang terperkara. Dasar hukum pemeriksaan setempat (gerechtelijke plaatsopneming) dalam hukum acara perdata terdapat pada Pasal 153 HIR, Pasal 180 RBg serta Pasal 211 Rv - Pasal 214 Rv. ${ }^{4}$

Objek barang terperkara yang dimaksud dalam pemeriksaan setempat (gerechtelijke plaatsopneming), antara lain : ${ }^{5}$

a. Benda tidak bergerak, seperti tanah atau kapal.

b. Benda bergerak, dengan syarat apabila benda tersebut sulit atau tidak mungkin untuk diajukan di sidang pengadilan.

Pelaksanaan pemeriksaan setempat (gerechtelijke plaatsopneming) dilakukan oleh salah satu hakim atau majelis hakim dengan dibantu oleh seorang panitera yang akan bertindak membuat berita acara, serta dihadiri pula para pihak yang berperkara dengan mendatangi tempat objek barang terperkara.

\section{Tinjauan Umum mengenai Proses Persidangan Dengan Acara Pemeriksaan Biasa}

Hukum acara pidana (hukum pidana formil) adalah keseluruhan aturan hukum yang mengenai cara melaksanakan ketentuan hukum pidana apabila terjadi pelanggaran terhadap norma-norma yang terkandung dalam hukum pidana tersebut. Pemeriksaan perkara dalam hukum acara pidana diatur dalam Bab XVI KUHAP.

Berdasarkan Bab XVI KUHAP tersebut, acara pemeriksaan perkara pidana di persidangan terdiri atas 3 (tiga) jenis, antara lain : acara pemeriksaan biasa, acara pemeriksaan singkat, acara pemeriksaan cepat.

Ditinjau dari segi pengaturan dan kepentingan, acara pemeriksaan biasa merupakan acara pemeriksaan yang paling utama dan paling luas pengaturannya. Hal ini didasarkan pada kenyataan bahwa dalam acara pemeriksaan biasa dilakukan

\footnotetext{
${ }^{4}$ Yahya Harahap, Hukum Acara Perdata Tentang Gugatan Persidangan, Penyitaan Pembuktian dan Putusan Pengadilan, Cetakan Kesepuluh, Penerbit: Sinar Grafika, Jakarta, 2010, hlm : 779781

$5 \quad$ Ibid, hlm : 785
} 
pemeriksaan perkara-perkara tindak pidana yang membutuhkan ketelitian dalam proses pembuktian di persidangan. ${ }^{6}$

Proses persidangan dengan acara pemeriksaan biasa dilakukan dengan pemeriksaan identitas terdakwa terlebih dahulu. Kemudian dilanjutkan dengan pembacaan surat dakwaan, hak mengajukan eksepsi, ruang lingkup pemeriksaan alat bukti, pemeriksaan barang bukti, penuntutan dan pembelaan, musyawarah hakim serta pengucapan putusan akhir.

\section{Tinjauan Umum mengenai Sistem Pembuktian Pidana}

Pembuktian merupakan ketentuan-ketentuan yang berisi penggarisan dan pedoman tentang cara-cara yang dibenarkan undang-undang membuktikan kesalahan yang didakwakan kepada Terdakwa. Pembuktian juga merupakan ketentuan yang mengatur alat-alat bukti yang dibenarkan undang-undang dan boleh dipergunakan hakim membuktikan kesalahan yang didakwakan.

Ada beberapa sistem atau teori pembuktian, yaitu antara lain:

a. Teori Pembuktian Berdasarkan Keyakinan Hakim Semata (Conviction In Time)

b. Teori Pembuktian Berdasar Keyakinan Hakim Atas Alasan Yang Logis (Conviction In Raisone)

c. Sistem Atau Teori Pembuktian Menurut Undang-Undang Secara Positif (Positief Wettelijk)

d. Teori Pembuktian Menurut Undang-undang Secara Negatif (Negatief Wettelijk Stelsel)

\section{Tinjauan Umum mengenai Putusan Dalam Perkara Pidana}

Putusan yang akan dijatukan pengadilan tergantung hasil musyawarah hakim yang bertitik tolak dari surat dakwaan dan pembuktian di persidangan. Putusan dalam perkara pidana tersebut dapat berbentuk putusan bebas, putusan lepas ataupun putusan pemidanaan.

\section{A.5. METODE PENELITIAN}

Metode penelitian tesis ini, mencakup hal-hal seperti berikut :

1. Pendekatan Masalah

Penelitian tesis ini tergolong ke dalam penelitian hukum normatif, yaitu "Penelitian hukum yang dilakukan dengan cara meneliti bahan pustaka atau data sekunder belaka. ${ }^{8}$

\footnotetext{
${ }^{6}$ Yahya Harahap, Pembahasan Permasalahan dan Penerapan KUHAP, Pemeriksaan Sidang Pengadilan, Banding dan Peninjauan Kembali, Edisi Kedua, Cetakan Kelima, Penerbit: Sinar Grafika, Jakarta, 2000, hlm : 109

${ }^{7}$ Ibid, HIm : 273

${ }^{8}$ Soerjono Soekanto, Sri Mamudji, Penelitian Hukum Normatif Suatu Tinjauan Singkat, Penerbit: PT. Raja Grafindo Persada, Jakarta, 2004, hlm: 13-14.
} 
2. Spesifikasi Penelitian

Dilihat dari spesifikasinya, rencana penelitian tesis ini merupakan penelitian deskriptif analitis, yakni: "Suatu penelitian yang berusaha memberikan gambaran secara menyeluruh, mendalam, tentang suatu keadaan atau gejala yang diteliti. ${ }^{9}$

3. Jenis Data

Penelitian hukum yang bersifat normatif, secara umum menggunakan jenis data yang terarah pada penelitian data sekunder.

Data sekunder merupakan sumber data penelitian yang diperoleh peneliti secara tidak langsung melalui media perantara (diperoleh dan dicatat oleh pihak lain). Data sekunder umumnya berupa bukti, catatan atau laporan historis yang telah tersusun dalam arsip (data dokumenter) yang dipublikasikan dan yang tidak dipublikasikan. ${ }^{10}$

4. Metode Pengumpulan Data

Dalam penelitian tesis ini, pengumpulan bahan hukum dilakukan melalui studi kepustakaan (library research), studi dokumenter, yaitu dengan meneliti beberapa dokumen hukum menyangkut pemeriksaan setempat (gerechtelijke plaatsopneming).

5. Metode Analisis Data

Data yang terkumpul dari hasil penelitian dilakukan analisa dengan metode analisis normatif kualitatif. Metode analisis kualitatif adalah suatu tata cara penelitian yang menghasilkan data deskriptif-analitis, yaitu apa yang dinyatakan oleh responden secara tertulis atau lisan, dan juga prilaku yang nyata, yang diteliti dan dipelajari sebagai sesuatu yang utuh."11 Selanjutnya data-data tersebut, dianalisis apakah sesuai dengan ketentuan-ketentuan normatifnya.

\section{A. HASIL PENELITIAN DAN PEMBAHASAN}

\section{B . 1 . Kebijakan Aplikasi Pemeriksaan Setempat Dalam Hukum Acara Pidana Pada Saat Ini}

9 Ronny Hanitijo Soemitro, Metodologi Penelitian Hukum dan Jurimetri, Penerbit: Ghalia Indonesia, Jakarta, 1990, hlm: 58.

10 http://nagabiru86.wordpress.com/2009/06/12/data-sekunder-dan-data-primer/

${ }^{11}$ Soerjono Soekanto, Pengantar Penelitian Hukum, Cetakan Pertama, Penerbit: Universitas Indonesia (UI-Press), Jakarta, 1981, hlm: 250. 
Kebijakan aplikasi pemeriksaan setempat pada proses persidangan perkara pidana saat ini merupakan penerobosan yang dilakukan oleh hakim dalam hukum acara pidana. Hal ini disebabkan, karena di dalam Kitab Undang-undang Hukum Acara Pidana (KUHAP) tidak ada ketentuan (recht vacuum) mengenai pelaksanaan pemeriksaan setempat tersebut. Latar belakang kebijakan aplikasi pemeriksaan setempat dalam hukum acara pidana di Indonesia pada saat ini, dapat di analisis secara yuridis dengan ditinjau dari proses persidangan perkara-perkara pidana di Indonesia serta pertimbangan hukum putusan perkara tersebut.

Berikut penulis sajikan perkara pidana serta kajian yuridis mengenai perkaraperkara pidana yang menggunakan pemeriksaan setempat dalam proses persidangannya, antara lain :

a. Perkara pidana nomor : 198/Pid.B/2009/PN.Ung jo nomor : 37/Pid/2010/PT.Smg jo nomor : 1074K/PID/2010.

Berdasarkan pertimbangan hukum putusan dalam perkara pidana nomor : 198/Pid.B/2009/PN.Ung, Majelis Hakim menyebutkan bahwa untuk menambah keyakinan maka majelis hakim melakukan pemeriksaan setempat. Pertimbangan hukum putusan tersebut tertuang pada halaman 20-21, sebagai berikut :

Menimbang, bahwa saksi-saksi Paulus Januarko, Caecilia Kartini, Henricus Joko Wiryono telah memberikan keterangan berdasarkan apa yang mereka lihat, dengar dan alami sendiri yaitu antara lain bahwa saksi Caecilia Kartini selaku ibu mertua terdakwa datang ke RSIA Anugerah Semarang untuk menengok cucunya yang baru lahir dimana pada awalnya saksi merasa senang dan bangga melihat cucu laki-lakinya yang diberi nama Abel yang parasnya ganteng dan kulitnya putih, namun saksi bertanya dalam hatinya kenapa cucunya tidak ada kemiripan dengan bapaknya, wajahnya berbeda, berkulit putih dan rambutnya pirang demikian juga saksi Henricus Joko Wiryono yang menengok anak terdakwa pada bulan Januari 2007 dirumah terdakwa dimana anak tersebut telah berumur sekitar 4 bulan, setelah melihat anak tersebut secara spontan saksi berkata kepada saksi Paulus Januarko " Elu perbaikan keturunan nih, anak lu kayak bule" .

Menimbang, bahwa Majelis Hakim dengan maksud untuk menambah keyakinan atas keterangan para saksi tersebut bermaksud akan melihat secara langsung fisik anak terdakwa dengan melakukan Pemeriksaan Setempat dirumah terdakwa namun sampai dirumah terdakwa dengan berbagai alasan terdakwa tidak bersedia menunjukkan anaknya kepada Majelis Hakim, selanjutnya dipersidangan terdakwa menyatakan keberatannya jika anaknya dihadirkan dipersidangan dan tetap berpendirian bahwa fisik anak tersebut mirip dengan fisik terdakwa yang berkulit putih dan berambut hitam karena masih ada keturunan Cina .

Menimbang, bahwa pernyataan terdakwa yang menyatakan bahwa anak yang dilahirkannya mempunyai ciri-ciri fisik mirip dengan terdakwa namun tidak didukung oleh bukti-bukti, sedangkan saksi-saksi memberikan keterangan 
dibawah sumpah sehingga keterangannya mempunyai nilai pembuktian, oleh karenanya Majelis Hakim berkeyakinan bahwa anak yang dilahirkan oleh terdakwa mempunyai ciri-ciri fisik mirip orang bule dengan kulit berwarna putih dan berambut pirang.

Menurut penulis dari uraian di atas, diketahui bahwa pada proses persidangan hakim melaksanakan pemeriksaan setempat. Pemeriksaan setempat tersebut bertujuan untuk menambah keyakinan hakim terhadap keterangan para saksi yang bertolak belakang dengan keterangan terdakwa di persidangan. Meskipun pemeriksaan setempat tersebut tidak diatur di dalam Kitab Undangundang Hukum Acara pidana, namun hakim bersikap aktif untuk mencari kebenaran materiil dalam perkara tersebut.

b. Perkara pidana nomor : 235/Pid.B/2010/PN.Ung

Pada proses persidangan perkara pidana nomor :235/Pid.B/2010/PN.Ung, telah diadakan pemeriksaan setempat mengenai pemeriksaan barang bukti dalam perkara tersebut. Sehingga di dalam pertimbangan putusan seharusnya di pertimbangkan masalah barang bukti yang dihubungkan dengan pelaksanaan pemeriksaan setempat. Akan tetapi, pada pertimbangan hukum putusan perkara pidana nomor :235/Pid.B/2010/PN.Ung tidak mempertimbangkan secara rinci mengenai pemeriksaan setempat.

Hal tersebut disebabkan dalam pertimbangan hukum putusan perkara pidana nomor :235/Pid.B/2010/PN.Ung hanya menegaskan bahwa segala hal yang tertuang dalam berita acara pemeriksaan dianggap sebagai satu kesatuan yang tidak terpisahkan dengan putusan. Selain itu, pertimbangan hukum dalam perkara tersebut hanya mempertimbangkan barang bukti sebagaimana bunyi amar putusan. Bunyi pertimbangan hukum mengenai barang bukti dalam putusan perkara pidana nomor :235/Pid.B/2010/PN.Ung, adalah sebagai berikut

Menimbang, bahwa untuk singkatnya uraian putusan ini segala sesuatu yang terjadi dipersidangan yang tertuang dalam Berita Acara Pemeriksaan haruslah dianggap dan merupakan suatu kesatuan yang tidak terpisahkan dengan putusan ini.

Menimbang, bahwa barang bukti yang diajukan dipersidangan akan diputuskan sebagaimana dalam amar putusan dibawah ini.

Menurut penulis dari uraian di atas, diketahui bahwa tujuan majelis hakim melaksanakan pemeriksaan setempat dalam proses persidangan untuk memeriksa barang bukti dalam perkara pidana nomor :235/Pid.B/2010/PN.Ung berupa tabung gas yang berjumlah ratusan buah dan dengan ukuran tabung gas 
$3 \mathrm{~kg}, 12 \mathrm{~kg}$ serta $50 \mathrm{~kg}$. Secara fakta notoir, keberadaan tabung-tabung gas tersebut termasuk merupakan kategori benda yang membahayakan. Sehingga berdasarkan Pasal 45 Ayat (1) huruf b, barang bukti berupa tabung gas tersebut diamankan oleh penuntut umum ke tempat penyimpanan tabung gas di Dsn. Ngablak Rt.02 Rw.05 Kec. Candirejo, Kec. Ungaran Barat, Kab. Semarang.

Pada hakikatnya pemeriksaan setempat dalam perkara ini dilaksanakan untuk menjalankan ketentuan pada Pasal 181 KUHAP. Pasal 181 KUHAP mengatur bahwa hakim ketua sidang memperlihatkan kepada terdakwa segala barang bukti dan menanyakan kepadanya apakah ia mengenal benda itu dengan memperhatikan ketentuan sebagaimana maksud dalam Pasal 45 KUHAP. Sehingga, majelis hakim dalam perkara pidana nomor :235/Pid.B/2010/PN.Ung. mengadakan pemeriksaan setempat untuk memperlihatkan kepada terdakwa segala barang bukti dan menanyakan kepadanya apakah ia mengenal benda itu.

Namun faktanya, para terdakwa tidak ikut dalam pelaksanaan pemeriksaan setempat tersebut. Pemeriksaan setempat dalam perkara pidana nomor :235/Pid.B/2010/PN.Ung. hanya dilakukan oleh majelis hakim yang didampingi oleh panitera pengganti, penuntut umum serta penasihat hukum terdakwa I. Padahal keberadaan penasihat hukum terdakwa dalam proses persidangan pidana hanya merupakan suatu hak yang dimiliki oleh Terdakwa, hal ini berdasarkan Pasal 56 KUHAP. Sedangkan berdasarkan Pasal 154 KUHAP, proses persidangan dalam acara pemeriksaan biasa dilaksanakan dengan kehadiran terdakwa. Oleh karena itu, maka pelaksanaan pemeriksaan setempat dalam perkara pidana nomor :235/Pid.B/2010/PN.Ung kurang tepat karena dilaksanakan tanpa kehadiran para terdakwa.

c. Perkara pidana nomor : 95/Pid.Sus/2010/PN.Ska

Majelis hakim mengadili dan memeriksa perkara pidana nomor : 95/Pid.Sus/2010/PN.Ska dengan menggunakan acara pemeriksaan biasa. Pada pertimbangan hukum putusan tersebut, Majelis Hakim mempertimbangkan mengenai pelaksanaan pemeriksaan setempat yang dilakukan pada saat persidangan berjalan. Pertimbangan hukum putusan tersebut tertuang pada halaman 21-22, sebagai berikut :

Menimbang, bahwa terhadap perkara ini Majelis telah melakukan pemeriksaan setempat, dimana hasilnya adalah sebagai berikut : 
- Bahwa objek sengketa terletak di Jalan Brigjen Sudiarto No.155, Surakarta, yakni berupa tanah dan bangunan yang berdiri di atasnya dalam posisi menghadap ke barat;

- Bahwa rumah tersebut merupakan unit bangunan yang menyatu dan telah dibagi waris dengan pembagian Terdakwa mendapatkan bagian selatan, Beny bagian tengah serta Cindy Ong bagian utara;

- Bahwa kemudian Beny menjual kepada saksi Ranu Wijaya;

- Bahwa setelah dibagi, bagian masing- masing tetap menyatu dengan rumah tersebut tanpa ada sekat, dimana pintu masuk hanya satu;

- Bahwa terdakwa dan keluarganya tidur di bagian selatan yang merupakan bagiannya, namun bagian Terdakwa tersebut pas- pasan untuk kamar tidur;

- Bahwa kompor, mesin cuci Terdakwa diletakkan di bagian Beny yang telah dibeli oleh Ranu Wijaya, sehingga kegiatan memasak dan mandi Terdakwa dan keluarganya menggunakan bagian yang telah dibeli oleh Ranu Wijaya;

- Bahwa di bagian yang telah dibeli oleh Ranu Wijaya terdapat 1 (satu) set kursi tamu dimana hal tersebut sering digunakan oleh Terdakwa untuk duduk- duduk dengan keluarganya serta menerima tamu;

Pertimbangan hukum mengenai pemeriksaan setempat tersebut, kemudian dihubungkan dengan keterangan saksi, keterangan ahli dan bukti surat merupakan fakta-fakta yang diperoleh dipersidangan. Fakta-fakta persidangan tersebut, menjadi pertimbangan hukum oleh majelis hakim pada perkara pidana nomor : 95/Pid.Sus/2010/PN.Ska untuk membuktikan apakah terdakwa melakukan perbuatan sesuai dengan dakwaan penuntut umum.

Menurut Penulis dari uraian di atas, diketahui bahwa pada proses persidangan perkara pidana nomor : 95/Pid.Sus/2010/PN.Ska, hakim melaksanakan pemeriksaan setempat. Tujuan pemeriksaan setempat pada perkara pidana nomor : 95/Pid.Sus/2010/PN.Ska adalah menambah keterangan bagi hakim yang dihubungkan dengan keterangan saksi, keterangan ahli dan bukti surat untuk mempertimbangkan unsur-unsur tindak pidana. Meskipun pemeriksaan setempat tersebut tidak diatur di dalam Kitab Undang-undang Hukum Acara pidana, namun hakim bersikap aktif untuk mencari kebenaran materiil dalam perkara tersebut.

Sehingga berdasarkan pemaparan ketiga perkara pidana di atas, penulis dapat menyimpulkan bahwa kebijakan aplikasi pemeriksaan setempat dalam hukum acara pidana pada saat ini, merupakan kebijakan penemuan hukum oleh hakim. Kebijakan penemuan hukum oleh hakim mengenai pemeriksaan setempat, dilakukan dengan metode konstruksi hukum. Kebijakan aplikasi pemeriksaan setempat dalam hukum acara pidana, dilaksanakan berdasarkan hati nurani hakim. Sehingga, kebijakan aplikasi pemeriksaan setempat tersebut, merupakan perwujudan dari keadilan 
substantif. Selain itu, kebijakan pemeriksaan setempat merupakan kebijakan yang dilaksanakan hakim untuk menerapkan asas peradilan yang cepat.

\section{B.2. Fungsi Pemeriksaan Setempat Dalam Pertimbangan Hukum Putusan Perkara Pidana}

Pertimbangan hukum suatu putusan perkara pidana harus diuraikan secara lengkap. Hal-hal yang diuraikan dalam pertimbangan hukum, antara lain :

1. Fakta dan keadaan harus jelas diuraikan sesuai dengan apa yang ditemukan dalam pemeriksaan di pengadilan.

2. Pembuktian yang diperoleh dari pemeriksaan di sidang yang menjadi dasar penentuan kesalahan terdakwa.

Penguraian fakta dan keadaan serta alat bukti dalam pertimbangan hukum suatu putusan perkara pidana harus diuraikan secara deskriptif, dipertimbangkan secara argumentatif yang logis dan reasoning sehingga mendukung kesimpulan dalam petimbangan hakim. $^{12}$

Berdasarkan pembahasan sub bab B.1 mengenai kasus dan analisis terhadap pemeriksaan setempat, maka penulis berpendapat mengenai fungsi pemeriksaan setempat dalam pertimbangan hukum putusan perkara pidana. Fungsi pemeriksaan setempat, antara lain : sebagai keyakinan hakim, penetapan penyerahan barang bukti serta menambah keterangan bagi hakim.

\section{B.3. Dampak Yuridis Pemeriksaan Setempat Dalam Hukum Acara Pidana}

Berdasarkan pembahasan sub bab B.1 mengenai kasus dan analisis terhadap pemeriksaan setempat, maka dampak yuridis pemeriksaan setempat (gerechtelijke plaatsopneming) yang timbul dalam hukum acara pidana, adalah tidak adanya unifikasi (keseragaman) aturan mengenai pemeriksaan setempat dalam praktik hukum acara pidana karena terdapat kekosongan hukum. Padahal untuk menjalankan hukum acara pidana di Indonesia, harus berpedoman pada asas legalitas yang menghendaki bahwa suatu peraturan dapat diterapkan apabila ada peraturan yang mengatur sebelumnya.

Ketidakseragaman pelaksanaan pemeriksaan setempat dalam perkara pidana, antara lain :

1. Ketidakseragaman mengenai para pihak yang mengikuti pemeriksaan setempat dalam perkara pidana.

Pemeriksaan setempat merupakan salah satu bagian dari proses persidangan perkara pidana. Proses persidangan pada saat dilaksanakannya pemeriksaan

\footnotetext{
${ }^{12}$ Yahya Harahap, Pembahasan Permasalahan Dan Penerapan KUHAP... Op Cit, hlm :361
} 
setempat dilakukan di tempat objek pemeriksaan setempat yang lokasinya berada di luar ruang sidang pengadilan. Sehingga pada hakikatnya pemeriksaan setempat sama dengan proses persidangan yang berlangsung di dalam ruang sidang. Hal yang membedakan pemeriksaan setempat dengan pemeriksaan yang berlangsung di dalam ruang sidang hanya lokasi pemeriksaannya saja. Selebihnya, mengenai pimpinan sidang maupun para pihak yang hadir dalam pemeriksaan setempat adalah sama dengan pemeriksaan yang berlangsung di dalam ruang sidang.

Dengan merujuk contoh pemeriksaan setempat dalam perkara pidana nomor :235/Pid.B/2010/PN.Ung dilaksanakan untuk menjalankan ketentuan pada Pasal 181 KUHAP. Sehingga majelis hakim dalam perkara pidana tersebut mengadakan pemeriksaan setempat untuk memperlihatkan kepada terdakwa segala barang bukti dan menanyakan kepadanya apakah ia mengenal benda itu.

Namun faktanya, para terdakwa tidak ikut dalam pelaksanaan pemeriksaan setempat tersebut. Pemeriksaan setempat dalam perkara pidana nomor :235/Pid.B/2010/PN.Ung. hanya dilakukan oleh majelis hakim yang didampingi oleh panitera pengganti, penuntut umum serta penasihat hukum terdakwa I. Padahal keberadaan penasihat hukum terdakwa dalam proses persidangan pidana merupakan suatu hak yang dimiliki oleh Terdakwa, hal ini berdasarkan Pasal 56 KUHAP. Sedangkan berdasarkan Pasal 154 KUHAP, proses persidangan dalam acara pemeriksaan biasa dilaksanakan dengan kehadiran terdakwa. Sehingga pada perkara ini, hakim sebagai aparat penegak hukum tidak memperhatikan asas-asas dalam hukum acara pidana yaitu asas pemeriksaan persidangan dihadiri dengan Terdakwa.

2. Uraian pemeriksaan setempat dalam pertimbangan hukum pada putusan perkara pidana.

Dalam pertimbangan hukum suatu putusan perkara pidana, diharapkan dapat menguraikan secara rinci mengenai pemeriksaan setempat (gerechtelijke plaatsopneming). Hal ini, bertujuan agar rasa keadilan dan kemanfaatan bagi para pencari keadilan tertuang dalam pertimbangan hukum putusan perkara pidana.

Dengan merujuk contoh pertimbangan hukum yang terdapat pada perkara pidana nomor :235/Pid.B/2010/PN.Ung tidak menguraikan mengenai pelaksanaan pemeriksaan setempat secara rinci dan argumentatif. Berikut penulis paparkan pertimbangan hukum mengenai pelaksanaan pemeriksaan setempat dalam putusan perkara pidana nomor :235/Pid.B/2010/PN.Ung : 
Menimbang, bahwa untuk singkatnya uraian putusan ini segala sesuatu yang terjadi dipersidangan yang tertuang dalam Berita Acara Pemeriksaan haruslah dianggap dan merupakan suatu kesatuan yang tidak terpisahkan dengan putusan ini.

Menimbang, bahwa barang bukti yang diajukan dipersidangan akan diputuskan sebagaimana dalam amar putusan dibawah ini.

Berdasarkan pemaparan di atas, penulis berpendapat bahwa pertimbangan hukum pelaksanaan pemeriksaan setempat dalam putusan perkara pidana nomor :235/Pid.B/2010/PN.Ung tersebut tidak jelas. Hal ini dikarenakan uraian pelaksanaan pemeriksaan setempat dalam perkara tersebut hanya terdapat pada berita acara persidangannya saja. Selain itu, pada pertimbangan hukum putusan perkara pidana nomor :235/Pid.B/2010/PN.Ung mengenai barang bukti harus di paparkan perbedaan yang terdapat dalam surat penyitaan barang bukti dengan fakta yang ditemukan pada saat pemeriksaan setempat. Kemudian majelis hakim juga harus mempertimbangkan mengenai latar belakang penetapan penyerahan barang bukti. Misal ; di dalam persidangan barang bukti berupa tabung gas telah terbukti merupakan alat yang digunakan untuk melakukan tindak pidana. Oleh karena itu, maka majelis hakim menetepkan barang bukti tersebut dirampas dan dimusnahkan.

Sehingga berdasarkan uraian di atas, masih terdapat ketidakseragaman mengenai pemeriksaan setempat dalam pertimbangan hukum putusan perkara pidana. Hal tersebut disebabkan adanya kekosongan hukum mengenai pemeriksaan setempat. Padahal untuk menjalankan hukum acara pidana di Indonesia, harus berpedoman pada asas legalitas. Asas legalitas menghendaki bahwa suatu peraturan dapat diterapkan apabila ada peraturan yang mengatur sebelumnya. Sehingga, perlu kebijakan pembaharuan dalam hukum acara pidana mengenai pelaksanaan pemeriksaan setempat.

\section{B.4. Formulasi Pemeriksaan Setempat dalam Pembaharuan Kitab Hukum Acara Pidana Yang Akan Datang}

Kebijakan pembaharuan dalam hukum acara pidana diharapkan menjadi pedoman untuk unifikasi / keseragaman aplikas pemeriksaan setempat dalam hukum acara pidana. Pembaharuan ketentuan mengenai pemeriksaan setempat secara jelas dibutuhkan dalam tataran ruang lingkup dan tata cara pemeriksaan setempat.

Ruang lingkup pemeriksaan setempat dalam hukum acara pidana dilaksanakan apabila menurut penilaian hakim perlu dilaksanakan pemeriksaan setempat. Pelaksanaan pemeriksaan setempat dalam hukum acara pidana bertujuan untuk menambah keyakinan hakim, keterangan bagi hakim dan penetapan penyerahan barang bukti. 
Tata cara / proses pemeriksaan setempat (gerechtelijke plaatsopneming) dilakukan dengan cara sebagai berikut :

1. Persidangan di buka di dalam ruang sidang. Kemudian sidang di skors oleh hakim ketua untuk melaksanakan pemeriksaan setempat (gerechtelijke plaatsopneming).

2. Kemudian para pihak yang terkait, seperti majelis hakim yang didampingi oleh panitera, penuntut umum serta terdakwa yang didampingi penasihat hukum (apabila ada), langsung menuju ke tempat objek pemeriksaan setempat ;

3. Setelah sampai di tempat, Hakim yang memimpin pemeriksaan setempat (gerechtelijke plaatsopneming) membuka secara resmi sidang pemeriksaan setempat.

4. Kemudian atas pertanyaan hakim, para pihak yang hadir memberikan keterangan terkait dengan objek pemeriksaan setempat. Apabila para pihak akan mengajukan saksi untuk memberikan keterangan mengenai objek pemeriksaan setempat, maka saksi tersebut dapat memberikan keterangan di bawah sumpah.

5. Apabila pemeriksaan setempat telah selesai dilakukan, maka hakim menutup sidang pemeriksaan setempat tersebut.

6. Kemudian majelis hakim berserta para pihak kembali lagi ke ruang sidang, untuk mencabut skors persidangan dan mengumumkan penundaan sidang.

Proses pemeriksaan setempat (gerechtelijke plaatsopneming) tersebut, tidak ada bedanya dengan proses persidangan di ruang sidang pengadilan. Segala sesuatu yang berkenaan dengan tata tertib dan hak serta asas yang semestinya ditegakkan, berlaku sepenuhnya pada sidang pemeriksaan setempat.

Berdasarkan pemaparan pembaharuan hukum dalam ruang lingkup dan tata cara pemeriksaan setempat pada hukum acara pidana, diharapkan praktik pemeriksaan setempat dalam perkara pidana tidak lagi terjadi kekosongan norma (vacuum of norm) dan terdapat unifikasi dalam aplikasi pemeriksaan setempat. Hal tersebut, bertujuan untuk meciptakan kepastian hukum bagi pencari keadilan dalam rangka lebih mengefektifkan penegakan hukum (law enforcement) yang diperankan oleh hakim sebagai sub unsur sistem peradilan pidana di Indonesia. 


\section{B. PENUTUP}

\section{C.1. Kesimpulan}

Berdasarkan uraian yang telah penulis sampaikan, maka dapat dirumuskan beberapa kesimpulan, sebagai berikut:

1. Kebijakan aplikasi pemeriksaan setempat dalam hukum acara pidana pada saat ini merupakan kebijakan penemuan hukum oleh hakim. Kebijakan penemuan hukum oleh hakim mengenai pemeriksaan setempat, dilakukan dengan metode konstruksi hukum. Kebijakan aplikasi pemeriksaan setempat dalam hukum acara pidana, dilaksanakan berdasarkan hati nurani hakim. Sehingga, kebijakan aplikasi pemeriksaan setempat tersebut, merupakan perwujudan dari keadilan substantif. Selain itu, kebijakan pemeriksaan setempat merupakan kebijakan yang dilaksanakan hakim untuk menerapkan asas peradilan yang cepat.

2. Berdasarkan analisis praktik pelaksanaan pemeriksaan setempat di persidangan, maka fungsi pemeriksaan setempat dalam pertimbangan hukum putusan perkara pidana digunakan untuk keyakinan hakim, keterangan bagi hakim untuk menambah keyakinannya serta pertimbangan untuk menetapkan penyerahan barang bukti. Selain itu, kekuatan pembuktian pemeriksaan setempat dalam pertimbangan hukum putusan perkara pidana adalah bebas. Sehingga dalam penerapannya, pemeriksaan setempat bukan hal yang mutlak selalu dilaksanakan dalam persidangan.

3. Dampak yuridis pemeriksaan setempat (gerechtelijke plaatsopneming) dalam hukum acara pidana adalah tidak ada unifikasi (keseragaman) aturan mengenai pemeriksaan setempat dalam praktik hukum acara pidana. Contoh ketidakseragaman pelaksanaan pemeriksaan setempat dalam perkara pidana, antara lain : ketidakseragaman mengenai para pihak yang mengikuti pemeriksaan setempat dalam perkara pidana dan ketidakseragaman mengenai uraian pemeriksaan setempat dalam pertimbangan hukum pada putusan perkara pidana.

Ketidakseragaman pelaksanaan pemeriksaan setempat dalam perkara pidana tersebut dikarenakan terdapat kekosongan hukum. Padahal untuk menjalankan hukum acara pidana di Indonesia, harus berpedoman pada asas legalitas. Asas legalitas menghendaki bahwa suatu peraturan dapat diterapkan apabila ada peraturan yang mengatur sebelumnya. Sehingga apabila masih terdapat ketidakseragaman aturan dalam praktik hukum acara pidana yang disebabkan kekosongan hukum, maka perlu kebijakan pembaharuan dalam hukum acara pidana. 
4. Salah satu kebijakan pembaharuan dalam Kitab Hukum Acara Pidana yang akan datang adalah pembaharuan terhadap ketentuan pemeriksaan setempat secara jelas mengenai ruang lingkup dan tata cara pemeriksaan setempat. Sehingga dalam praktik peradilan pidana Indonesia, tidak terjadi kekosongan norma (vacuum of norm) mengenai pemeriksaan setempat dan terdapat unifikasi dalam aplikasi pemeriksaan setempat. Hal tersebut, bertujuan untuk menciptakan kepastian hukum bagi pencari keadilan dalam rangka lebih mengefektifkan penegakan hukum (law enforcement) yang diperankan oleh hakim sebagai sub unsur sistim peradilan pidana di Indonesia.

\section{C.2. Saran}

Berdasarkan pemaparan kesimpulan, dalam kesempatan ini penulis mengajukan beberapa saran, sebagai berikut:

1. Kebijakan aplikasi pemeriksaan setempat (gerechtelijke plaatsopneming), merupakan kebijakan yang berasal dari penemuan hukum oleh hakim. Hakim sebagai sub unsur sistim peradilan pidana di Indonesia hendaknya berorientasi pada ketentuan pasalpasal yang secara yuridis normatif telah diformulasikan dalam pembaharuan Kitab Undang-Undang Hukum Acara Pidana (KUHAP) yang akan datang. Sehingga aplikasi pemeriksaan setempat (gerechtelijke plaatsopneming) dapat menciptakan kepastian hukum bagi para pencari keadilan (justitiabelen).

2. Fungsi pemeriksaan setempat (gerechtelijke plaatsopneming) dalam pertimbangan hukum putusan perkara pidana digunakan untuk keyakinan hakim, keterangan bagi hakim untuk menambah keyakinannya serta pertimbangan untuk menetapkan penyerahan barang bukti. Oleh karena itu, maka dalam pertimbangan hukum putusan, diharapkan dapat menguraikan secara jelas dan lengkap mengenai pemeriksaan setempat (gerechtelijke plaatsopneming). Hal ini, bertujuan agar rasa keadilan dan kemanfaatan bagi para pencari keadilan, tertuang dalam pertimbangan hukum putusan perkara pidana.

3. Solusi hukum dari dampak yuridis yang terjadi dalam pelaksanaan pemeriksaan setempat dalam perkara pidana selama ini, adalah diperlukannya suatu pembaharuan hukum dalam ranah hukum acara pidana di Indonesia. Hal ini bertujuan agar tidak ada kekosongan hukum, sehingga terjadi unifikasi aturan mengenai pemeriksaan setempat dalam praktik hukum acara pidana. Selain itu, agar tidak ada kekeliruan prosedur dalam pelaksanaan pemeriksaan setempat (gerechtelijke plaatsopneming). 
4. Demi adanya kepastian hukum bagi para pencari keadilan terkait pemeriksaan setempat (gerechtelijke plaatsopneming), maka pembentuk undang-undang diharapkan memformulasikan secara jelas mengenai tata cara dan ruang lingkup pemeriksaan setempat (gerechtelijke plaatsopneming), dalam pembaharuan Kitab Undang-Undang Hukum Acara Pidana (KUHAP) yang akan datang 


\section{DAFTAR PUSTAKA}

\section{A. BUKU}

Abdullah, 2008, Pertimbangan Hukum Putusan Pengadilan, Penerbit : Program Pascasarjana Universitas Sunan Giri, Sidoarjo.

Achmad Ali, 1993, Menguak Tabir Hukum (Suatu Kajian Filosofis dan Sosiologis), Penerbit : Chandra Pratama, Jakarta.

Ahmad Rifai, Penemuan Hakim oleh Hakim Dalam Perspektif Hukum Progresif, Penerbit : Sinar Grafika, Jakarta, 2010

Amirudin dan H. Zainal Asikin, 2004, Pengantar Metode Penelitian Hukum, Penerbit: PT. Raja Grafindo Persada, Jakarta.

Ansorie Sabuan. et.al, 1990, Hukum Acara Pidana, Edisi ke-1, Cetakan ke-1, Penerbit: Angkasa, Bandung.

A. Siti Soetami, 2001, Pengantar Tata Hukum Indonesia Edisi Revisi 2001, Penerbit:Rafika Editama, Bandung .

Bachsan Mustafa, 2003, Sistim Hukum Indonesia Terpadu, Cetakan 1, Penerbit: PT. Citra Aditya Bakti, Bandung.

Bambang Sunggono, 2006, Metodelogi Penelitian Hukum, Penerbit: Rajawali Pers, Jakarta.

Balitbang Diklat Kumdil Mahkamah Agung RI, 2007, Buku II Pedoman Teknis Administrasi Dan Teknis Peradilan Perdata Umum, Penerbit : Mahkamah Agung RI, Jakarta.

Administrasi Dan Teknis Peradilan Pidana Umum Dan Pidana Khusus, Penerbit : Mahkamah Agung RI, Jakarta.

Barda Nawawi Arief, 2008, Bunga Rampai Kebijakan Hukum Pidana, Perkembangan Penyusunan Konsep KUHP Baru, Cetakan ke-1, Penerbit: Kencana Prenada Media Group, Jakarta.

Darwan Prinst, 1998, Hukum Acara Pidana Dalam Praktik, Penerbit : Djambatan, Jakarta.

Djoko Prakoso, 1985, Kedudukan Justisiabel di Dalam KUHAP, Cetakan Pertama, Penerbit: Ghalia Indonesia, Jakarta. 
Hari Sasangka, 2003, Komentar Kitab Undang-Undang Hukum Acara Pidana, Penerbit : Mandar Maju, Bandung.

Hari Sasangka dan Lily Rosita, 2003, Hukum Pembuktian Dalam Perkara Pidana, Penerbit : Mandar Maju, Bandung.

Harun M. Husein, Kasasi Sebagai Upaya Hukum, Cetakan Pertama, Penerbit: Sinar Grafika, Jakarta, 1992

Hilaire Mc. Coubrey and Nigel D. White, 1993, Texbook On Jurisprudence, Second Edition, Penerbit : Blacstone Press Ltd University of Nottingham, London.

H.S. Prajudi, A, 1973, Dasar-Dasar Office Manajemen, Penerbit: Ghalia, Jakarta

Jazim Hamidi, 2005, Hermeunetika Hukum, Teori Penemuan Hukum Baru dengan Interpretasi Teks, Penerbit : UII Press, Yogyakarta.

Johny Ibrahim, 2005, Teori \& Metodologi Penelitian Hukum Normatif, Penerbit : Bayumedia Publishing, Jakarta.

Leden Marpaung, 1995, Putusan Bebas Masalah dan Pemecahannya, Cetakan Pertama, Penerbit: Sinar Grafika, Jakarta.

Magister Ilmu Hukum Universitas Diponegoro, 2008, Peraturan Akademik dan Pedoman Penyusunan Tesis Magister Ilmu Hukum Universitas Diponegoro, Semarang.

Made Sadhi Astuti, 1997, Pemidanaan Terhadap Anak Sebagai Pelaku Tindak Pidana, Penerbit : IKIP Malang, Malang.

Martiman Prodjohamidjojo, 1984, Komentar Atas KUHAP, Kitab Undang-Undang Hukum Acara Pidana, Penerbit : Pradnya Paramita, Jakarta.

Mohammad Taufik Makarao dan Suhasril, 2010, Hukum Acara Pidana Dalam Teori Dan Praktek, Penerbit :Ghalia Indonesia, Bogor.

Moeslim Abdurrahman.et Al, 1996, Ensiklopedia Nasional Indonesia Jilid 15, Penerbit: P.T. Citra Adi Pustaka, Jakarta.

Mulyana W. Kusumah, 1981, Hukum, Keadilan dan Hak Asasi Manusia, Suatu Pemahaman Kritis, Penerbit : Alumni, Bandung.

Musanef, 1989, Sistim Pemerintahan di Indonesia, Penerbit: CV. Haji Masagung, Jakarta. 
Nyoman Serikat Putra Jaya, 2010, Bahan Kuliah Sistem Peradilan Pidana (Criminal Justice

System), Program Magister Ilmu Hukum Universitas Diponegoro Semarang, Semarang.

Pamudji, 1981, Teori Sistim dan Pengertiannya Dalam Manajemen, Penerbit: Ikhtiar Baru, Jakarta.

Paulus Hadisuprapto, 2010, Bahan Kuliah Magister Ilmu Hukum Universitas Diponegoro Semarang : Metodologi Penelitian Hukum, Universitas Diponegoro, Semarang.

Rd. Achmad S. Soema Di Pradja, 1981, Pokok-Pokok Hukum Acara Pidana Indonesia, Penerbit: Alumni, Bandung.

Riduan Syahrani, 1999, Rangkuman Intisari Ilmu Hukum, Cetakan Kedua, Penerbit: PT. Citra Aditya Bakti, Bandung.

Ronny Hanitijo Soemitro,1990, Metodologi Penelitian Hukum dan Jurimetri, Penerbit: Ghalia Indonesia.

Rosjidi Ranggawidjaja, 1998, Pengantar Ilmu Perundang-Undangan Indonesia, Penerbit: Mandar Maju, Bandung.

Soesilo Yuwono, 1982, Penyelesaian Perkara Pidana Berdasarkan K.U.H.A.P Sistem Dan Prosedur, Penerbit: Alumni, Bandung.

Soerjono Soekanto, 1981, Pengantar Penelitian Hukum, Cetakan Pertama, Penerbit: Universitas Indonesia (UI-Press), Jakarta.

Soerjono Soekanto, Sri Mamudji, 2004, Penelitian Hukum Normatif Suatu Tinjauan Singkat, Penerbit: PT. Raja Grafindo Persada, Jakarta.

Sri Sumanti, 1976, Sistim-Sistim Pemerintahan Negara-Negara, Penerbit: Tarsito, Bandung Subekti, 2001, Hukum Pembuktian, Penerbit : Pradnya Paramita, Jakarta.

Subekti, 2005, Pokok-Pokok Hukum Perdata, Cetakan XI, Penerbit: Intermasa, Jakarta.

Sudikno Mertokusumo, 2001, Penemuan Hukum Sebuah Pengantar, Penerbit : Liberty, Yogtakarta.

Sudikno Mertokusumo dan A. Pitlo, 1993, Bab-bab Tentang Penemuan Hukum, Penerbit : Citra Aditya Bakti, Jakarta.

Sunaryo Wignyodipuro, 1979, Ilmu Hukum, Cetakan ke II, Penerbit: Alumni, Bandung. 
Tatang M. Amirin, 2001, Pokok-Pokok Teori Sistim, Cetakan ke-7, Penerbit: PT. Raja Grafindo persada, Jakarta.

Utrecht, 1957, Pengantar Dalam Hukum Indonesia, Cetakan ke-4, Penerbit: Ikhtiar, Jakarta.

Wirjono Prodjodikoro, 1977, Hukum Acara Pidana di Indonesia, Cetakan Ketujuh, Penerbit: Sumur, Bandung.

Yahya Harahap, 2010, Hukum Acara Perdata Tentang Gugatan Persidangan, Penyitaan

Pembuktian dan Putusan Pengadilan Cetakan Kesepuluh, Penerbit : Sinar Grafika, Jakarta.

2008, Pembahasan Permasalahan Dan Penerapan KUHAP

Pemeriksaan Sidang Pengadilan, Banding, Kasasi dan Peninjauan Kembali, Penerbit : Sinar Grafika, Jakarta.

Yesmil Anwar dan Adang, 2011, Sistem Peradilan Pidana Konsep, Komponen \& Pelaksanaannya Dalam Penegakan Hukum Di Indonesia, Cetakan Kedua, Penerbit :Widya Padjajaran, Bandung.

\section{B. PERATURAN PERUNDANG-UNDANGAN}

Herzeine Inlandsch Reglement ( HIR )

Keputusan Menteri Kehakiman No.M.14-PW.07.03 Tahun 1983 pada tanggal 10 Desember 1983 tentang Tambahan Pedoman Pelaksanaan KUHAP

$\mathrm{RBg}$ (Rechtsreglement Buitengewesten)

$\mathrm{Rv}$ (Reglement op de Rechtsvordering)

Surat Edaran Mahkamah Agung No. 7 Tahun 1985 Petunjuk Pelaksanaan Tugas Hakim Pengawas Dan Pengamat

Surat Edaran Mahkamah Agung Nomor 6 Tahun 1992, tgl 21 oktober 1992 tentang azas peradilan yang sederhana, cepat dan biaya murah

Undang-Undang Dasar Negara Republik Indonesia Tahun 1945.

Undang-undang Nomor 1 Darurat Tahun 1951 Tindakan-Tindakan Sementara Untuk Menyelenggarakan Kesatuan Tindakan Sementara Untuk Menyelenggarakan Kesatuan Susunan Kekuasaan Dan Acara Pengadilan-Pengadilan Sipil.

Undang-undang Nomor 7 Tahun 1955 tentang tindak pidana ekonomi

Undang-undang Nomor 11 (PNPS) Tahun 1963 tentang pemberantasan kegiatan subversi 
Undang-undang Nomor 14 Tahun 1970 tentang Pokok-Pokok Kekuasaan Kehakiman

Undang-undang Nomor 8 Tahun 1981 tentang Kitab Undang-undang Hukum Acara Pidana (KUHAP)

Undang-undang Nomor 4 Tahun 1992 tentang Perumahan dan Pemukiman

Undang-undang Nomor 8 Tahun 1997 tentang Dokumen Perusahaan

Undang-Undang Nomor 8 Tahun 1999 tentang Perlindungan Konsumen

Undang-undang Nomor 35 Tahun 1999 tentang Ketentuan-Ketentuan Pokok Kekuasaan Kehakiman

Undang-undang Nomor 20 Tahun 2001 tentang Perubahan Atas Undang-undang Nomor 31 Tahun 1999 tentang Pemberantasan Tindak Pidana Korupsi

Undang-undang Nomor 4 Tahun 2004 tentang Kekuasaan Kehakiman

Undang-undang Nomor 15 Tahun 2003 tentang Terorisme

Undang-undang Nomor 11 Tahun 2008 tentang Informasi Teknologi Elektronik

Undang-undang Nomor 48 Tahun 2009 tentang kekuasaan kehakiman

Undang-undang Nomor 8 Tahun 2010 tentang Pencegahan dan Pemberantasan Tindak Pidana Pencucian Uang

Yurisprudensi Mahkamah Agung : tgl. 30 Maret 1978 No. 436 K/Sip/1974 tentang Pemeriksaan Setempat

Yurisprudensi Putusan Reg.No.275K/Pid/1983 tentang Putusan Bebas

\section{DOKUMEN}

Berita Acara Sidang ketujuh Nomor : 198/Pid.B/2009/PN.Ung

Berita Acara Sidang kedelapan Nomor : 198/Pid.B/2009/PN.Ung

Berita Acara Sidang lanjutan keempat Nomor : 235/Pid.B/2010/PN.Ung

Putusan Mahkamah Agung Republik Indonesia Nomor : 1074K/PID/2010

Putusan Pengadilan Negeri Surakarta Nomor : 95/Pid.Sus/2010/PN.Surakarta

Putusan Pengadilan Negeri Ungaran Nomor : 198/Pid.B/2009/PN.Ung

Putusan Pengadilan Negeri Ungaran Nomor : 235/Pid.B/2010/PN.Ung

Putusan Pengadilan Tinggi Jawa Tengah di Semarang Nomor : 37/Pid/2010/PT.Smg 


\section{KAMUS}

Tim Redaksi Tata Nusa, 1999, Kamus Istilah Menurut Peraturan Perundang-undangan Republik Indonesia 1945-1998, Penerbit: PT. Tatanusa, Jakarta

\section{E. MAJALAH DAN SURAT KABAR}

Bagir Manan, 2006, Hakim dan Pemidanaan, Majalah Hukum Varia Peradilan Edisi No. 249 Bulan Agustus 2006, Ikahi, Jakarta.

Lintong O. Siahaan, 2006, Peran Hakim Agung dallam Penemuan Hukum dan Penciptaan Hukum pada Era Reformasi dan Transformasi, Majalah Hukum Varia Peradilan Tahun ke XXI No. 252 November 2006, Ikahi, Jakarta

Prija Djatmika, Problem Menegakkan Keadilan Substantif, Harian Jawa Pos, Rabu 10 Desember 2008

Soekarno, Dalih Verkapte Ontslag van Rechtvervolging, Majalah Pengayoman Nomor: 6, Tahun III, Juli, 1978

\section{F. MEDIA ELEKTRONIK}

http://translate.google.co.id/

http://www.google.com/ dampak yuridis pemeriksaan setempat (gerechtelijke plaatsopneming) dalam hukum acara pidana dipandang dari aspek pertimbangan hukum putusan pidana http://www.putusan.mahkamahagung.go.id 